\title{
The Metabolism of Amino Acids in the Bovine Lens
}

\author{
THEIR OXIDATION AS A SOURCE OF ENERGY
}

\author{
By P. TRAYHURN and RUTH VAN HEYNINGEN \\ Nuffield Laboratory of Ophthalmology, University of Oxford, \\ Walton Street, Oxford OX2 6AW, U.K.
}

(Received 27 March 1973)

\begin{abstract}
1. The metabolism by the bovine lens of nine ${ }^{14} \mathrm{C}$-labelled L-amino acids was studied. These were: alanine, aspartate, glutamate, leucine, lysine, proline, serine, tyrosine and tryptophan. 2. All were taken up by the tissue and incorporated into protein. 3. Aspartate and glutamate, although poorly taken up, were readily metabolized to $\mathrm{CO}_{2}$. Radioactivity from glutamate was also found in glutathione, glutamine, proline and ophthalmic acid. Aspartate was converted into glutamate, glutathione, proline, alanine and lactate. 4. Alanine was largely converted into lactate, which was released into the medium, but incorporation of radioactivity into $\mathrm{CO}_{2}$, glutamate, glutathione, aspartate and lipids also occurred. 5. Radioactivity from leucine was detected in $\mathrm{CO}_{2}$, lipids, glutamate, glutathione, proline and glutamine. 6 . Lysine was only slightly broken down by the bovine lens; radioactivity was observed in $\mathrm{CO}_{2}$, glutamate, glutathione, proline and two unidentified compounds. 7. Proline was metabolized to glutamate from which $\mathrm{CO}_{2}$, glutathione and glutamine were formed. Hydroxyproline in the capsule collagen was labelled. 8. Radioactivity from serine was found in $\mathrm{CO}_{2}$, lipids, glutathione, glycine, cystine, ATP, lactate and three unidentified compounds, one of which was probably taurine. 9. Neither tyrosine nor tryptophan were metabolized by the bovine lens. 10 . The ability of the lens to metabolize amino acids was also shown by measurement of $\mathrm{NH}_{3}$ production: more $\mathrm{NH}_{3}$ was formed when glucose was absent from the incubation medium. 11. These experiments suggest that oxidation of amino acids is a source of energy for the lens.
\end{abstract}

One-third of the wet weight and almost all of the dry weight of the mammalian lens is protein. The tissue maintains high concentrations of free amino acids against a concentration gradient with respect to the aqueous humour (Reddy \& Kinsey, 1962; Reddy; 1967). Several studies have been made on the active transport of L-amino acids into the lens (Kern, 1962; Kinsey \& Reddy, 1963; Reddy, 1970; Cotlier, 1971) but little is known about their metabolism in the tissue.

The incorporation of a radioactively labelled Lamino acid into lens proteins in vitro was first shown by Merriam \& Kinsey (1950b) and the incorporation of radioactivity from $\left[{ }^{14} \mathrm{C}\right]$ glucose into glutamate and alanine has been observed in the lens of several species (van Heyningen, 1965; Reddy, 1971). The metabolism of glycine and valine has been studied in the calf lens (Waley, 1964) and that of methionine in the lens of the rabbit (Dardenne \& Kirsten, 1962). Griffiths (1966) observed that a mitochondrial preparation from the adult bovine lens oxidized glutamate, and the formation of ${ }^{14} \mathrm{CO}_{2}$ from $\left[{ }^{14} \mathrm{C}\right]$ glutamate has been shown in the whole lens of the same species (Trayhurn \& van Heyningen, 1971a). Three enzymes involved in amino acid metabolism, glutamate dehydrogenase (EC 1.4.1.2), aspartate aminotransferase (EC 2.6.1.1) and alanine aminotransferase
(EC 2.6.1.2) are present in the adult bovine lens (Dardenne \& Kirsten, 1962).

Earlier work (Trayhurn \& van Heyningen, 1971a; Trayhurn, 1972) suggested that in the absence of added glucose, amino acids could be the endogenous substrates oxidized by the lens, with the production of energy. The work presented here was undertaken to obtain more information about this metabolism. Nine radioactively labelled L-amino acids were studied, namely alanine, aspartate, glutamate, leucine, lysine, proline, serine, tryptophan and tyrosine. The production of $\mathrm{NH}_{3}$ was also measured. A preliminary report of the results obtained for alanine, aspartate and glutamate has already been given (Trayhurn \& van Heyningen, 1971a).

\section{Experimental}

Materials

Adult bovine eyes were obtained from the slaughterhouse. The lenses were removed at the laboratory and used immediately, not more than $2.5 \mathrm{~h}$ after death. The wet weight of the lens varied from 1.9 to $2.1 \mathrm{~g}$.

Radioactively labelled amino acids were obtained from The Radiochemical Centre, Amersham, Bucks., 
U.K., in the following forms: $\mathrm{L}-\left[\mathrm{U}-{ }^{14} \mathrm{C}\right]$ alanine $(156 \mathrm{mCi} / \mathrm{mmol})$; L-[U- $\left.{ }^{14} \mathrm{C}\right]$ aspartate $\quad(229 \mathrm{mCi} /$ mmol); L-[U-14 C]glutamate $(260 \mathrm{mCi} / \mathrm{mmol}) ; \quad$ L[U- ${ }^{14}$ C]leucine $(331 \mathrm{mCi} / \mathrm{mmol}) ; \mathrm{L}-\left[\mathrm{U}-{ }^{14} \mathrm{C}\right] \mathrm{lysine}$ hydrochloride $(336 \mathrm{mCi} / \mathrm{mmol}) ; \quad$ L- $\left[\mathrm{U}-{ }^{14} \mathrm{C}\right]$ proline (265 mCi $/ \mathrm{mmol}) ; \mathrm{L}-\left[\mathrm{U}-{ }^{14} \mathrm{C}\right]$ serine $(162 \mathrm{mCi} / \mathrm{mmol})$; DL-[methylene $\left.-{ }^{14} \mathrm{C}\right]$ tryptophan $(50 \mathrm{mCi} / \mathrm{mmol}) ; \mathrm{L}-$ [U-14 C]tyrosine $(507 \mathrm{mCi} / \mathrm{mmol})$. Each was used at the specific radioactivity supplied. Their purity, which was checked by paper chromatography and electrophoresis, was greater than $99 \%$.

Sodium benzylpenicillin (B.P. grade) and streptomycinsulphate(B.P. grade) were obtained from Glaxo Laboratories Ltd., Greenford, Middx., U.K. $N$ Methyl dioctylamine was obtained from the British Hydrological Corp., Merton, Surrey, U.K.

All other chemicals were from BDH Chemicals Ltd., Poole, Dorset, U.K., and were of AnalaR Grade whenever available.

\section{Methods}

Incubation of the lenses. The culture tubes of Merriam \& Kinsey (1950a) were used. The basic medium was Krebs-Ringer phosphate buffer, pH7.4 (Cohen, 1949), with the $\mathrm{Ca}^{2+}$ concentration decreased to $\frac{1}{2} ; 1 \mathrm{ml}$ of a solution containing $10 \mathrm{mg}$ each of sodium benzylpenicillin and streptomycin sulphate $/ \mathrm{ml}$ was added to $99.0 \mathrm{ml}$ of Krebs-Ringer phosphate. Glucose $(1.0 \mathrm{M})$ solution was added to give a final concentration of $10 \mathrm{~mm}$. Each lens was incubated in $15.0 \mathrm{ml}$ of medium, containing $5.0 \mu \mathrm{Ci}$ of the radioactive amino acid, for $22 \mathrm{~h}$ in a continuously shaking water bath at $35^{\circ} \mathrm{C}$. A side arm, containing $0.5 \mathrm{ml}$ of $30 \%(\mathrm{w} / \mathrm{v}) \mathrm{NaOH}$, was attached to the culture tubes for the collection of ${ }^{14} \mathrm{CO}_{2}$. Air was used as the gas phase.

At the end of the incubation period the lenses were removed from the culture tubes, which were immediately restoppered. The medium was acidified by the addition of $1.0 \mathrm{ml}$ of $30 \%(\mathrm{w} / \mathrm{v})$ trichloroacetic acid to drive off dissolved $\mathrm{CO}_{2}$. The tubes were reincubated for $3 \mathrm{~h}$ to ensure complete recovery of the gas in the $\mathrm{NaOH}$.

Each lens, on removal from the medium, was blotted dry with filter paper. Any with an abnormal appearance or a broken capsule were discarded. The lens was next transferred to a weighed polythene centrifuge tube containing $10.0 \mathrm{ml}$ of $10 \%$ (w/v) trichloroacetic acid and the tube was reweighed. The lens was crushed with a glass rod and the tube left for $1 \mathrm{~h}$ at $4^{\circ} \mathrm{C}$ before centrifuging at $3000 \mathrm{~g}$. The supernatant was decanted and stored at $4^{\circ} \mathrm{C}$ until required and the firmly packed protein precipitate was processed at once. The water content of the bovine lens was taken to be $64.5 \%$ (Amoore et al., 1959) and in all calculations the total volume of the trichloroacetic acid extract was taken to be $(10+0.645 x) \mathrm{ml}$, where $x \mathrm{~g}$ is the weight of the lens. The volume of the decanted supernatant was more than $10 \mathrm{ml}$.

The protein precipitate was dissolved in $1 \mathrm{M}$ $\mathrm{NaOH}$ and left at room temperature for $1 \mathrm{~h}$ to destroy aminoacyl RNA (van Heyningen, 1965). The protein was reprecipitated with $30 \%(\mathrm{w} / \mathrm{v})$ trichloroacetic acid and then washed by centrifuging three times with $10 \%(w / v)$ trichloroacetic acid followed by two washings with acetone and one with ether. The $\mathrm{NaOH}$ containing $\mathrm{Na}^{14} \mathrm{CO}_{3}$ was transferred from the side arm of the culture tube and the $\mathrm{Ba}^{14} \mathrm{CO}_{3}$ was precipitated (Udenfriend \& Cooper, 1952).

Separation and identification of the radioactive compounds in the trichloroacetic acid-soluble material. Trichloroacetic acid was removed from the lens supernatant with $N$-methyl dioctylamine (Hughes \& Williamson, 1951). The components in the extract were separated by low-voltage paper electrophoresis (Whatman no. 52 paper) at $\mathrm{pH} 1.6$ followed by paper chromatography at right angles in solvent 1 (see below), essentially as described by Calam (1962) and Calam \& Waley (1964). The papers were then radioautographed and the radioactive spots tentatively identified by reference to markers, and a published 'map' for lens extracts (Calam, 1962), and by the use of ninhydrin (Atfield \& Morris, 1961) and isatin (Smith, 1969) stains. Further information was obtained by the use of performic acid oxidation and acid hydrolysis (see below).

The radioactive spots were cut out from the paper, placed on planchets, each side was counted for radioactivity and the count-rate averaged (van Heyningen, 1965). They were then eluted from the paper with water, dried under vacuum and dissolved in a nonradioactive solution of the suspected substance. The material was subjected to paper chromatography, in the two solvent systems, followed by radioautography. Finally the papers were stained with ninhydrin and isatin, and the identity of the compound was confirmed by the coincidence, in both solvent systems, of the stained and radioactive spots.

Electrophoresis and chromatography solvents. These were, at $\mathrm{pH} 1.6,125 \mathrm{ml}$ of $98 \%(\mathrm{v} / \mathrm{v})$ formic acid and $375 \mathrm{ml}$ of acetic acid made up to 2.5 litres with water; (1) butan-1-ol-acetic acid-water (12:3:5, by vol.);(2) phenol-water $(4: 1, \mathrm{w} / \mathrm{v})$ containing $0.5 \%$ $\mathrm{NH}_{3}$, sp.gr. 0.88 .

Performic acid oxidation. This was done by the method of Hirs (1967).

Acid hydrolysis. This was done in vacuo in $6 \mathrm{M}-\mathrm{HCl}$, at $108^{\circ} \mathrm{C}$, for $18 \mathrm{~h}$.

Glutamine. This was always found after two-dimensional chromatography as pyrrolidone-5-carboxylate, presumably owing to ring closure caused by the trichloroacetic acid. Its identity was confirmed by converting it into glutamate by acid hydrolysis in $2 \mathrm{M}-\mathrm{HCl}$ for $2 \mathrm{~h}$ at $100^{\circ} \mathrm{C}$ (Gray \& Weitzman, 1969).

Lactate. Loss of lactate by evaporation from the 
chromatography paper was decreased by exposing the papers to $\mathrm{NH}_{3}$ fumes (Bradford et al., 1969) and performing the radioautography at $-20^{\circ} \mathrm{C}$ (BeloffChain et al., 1955).

Extraction and separation of lens lipids. In some cases the incorporation of radioactivity from the amino acid precursor into lens lipids was investigated. This was done in a separate experiment because the lipid content of the bovine lens is only $0.25 \%$ of the wet weight (Anderson et al., 1969). After incubation the lens was freeze-dried and the lipids were extracted (Trayhurn \& van Heyningen, 1971a). A sample of the extract was weighed and its radioactivity measured. A further sample was subjected to t.l.c. on a $250 \mu \mathrm{m}$ thick layer of silica gel GF 254 (E. Merck, A.-G., Darmstadt, Germany), in chloroform-methanol-water (14:6:1, by vol.) (Muldner et al., 1962). The plates were radioautographed and stained by exposure to $I_{2}$ vapour.

Radioautography. Chromatography papers and plates were radioautographed with Kodak Royal Blue $\mathrm{X}$-ray film. The usual exposure time was 2-3 weeks.

Measurement of radioactivity. Radioactivity was measured with an end-window Geiger-Muller counter. Samples were prepared on $4 \mathrm{~cm}^{2}$ aluminium planchets. Protein and liquid samples $(0.05$ or $0.10 \mathrm{ml})$ were prepared for measurement as described by van Heyningen (1965). With the exception of $\mathrm{Ba}^{14} \mathrm{CO}_{3}$, radioactivity was measured at 'infinite thinness'. A self-absorption correction was made for $\mathrm{Ba}^{14} \mathrm{CO}_{3}$. Sufficient radioactive counts were usually measured for the standard error to be less than $2.5 \%$.

Recovery of radioactivity. For each amino acid the recovery of the radioactivity from the experiment was determined. This is the sum of the radioactivity found after incubation, in $\mathrm{CO}_{2}$, protein, trichloroacetic acid-soluble material and the medium, expressed as a percentage of that originally in the medium. With the exception of serine the recoveries were between 90 and $102 \%$; in the case of serine the recovery was $85 \%$.

Expression of results. The radioactivity measurements are adjusted to a value for the initial radioactivity in the medium of 9000 c.p.s. $/ 15 \mathrm{ml}$. The uptake of the amino acid is defined as the sum of the radioactivity found in $\mathrm{CO}_{2}$, protein, acid-soluble material and, for alanine, lactate in the medium. This will be presumably a minimum value since some of the amino acid may have been taken up and subsequently diffused back into the medium. The measurements for the radioactivity in the compounds of the acid-soluble fraction are reported as a percentage of the total radioactivity in that fraction.

Estimation of $\mathrm{NH}_{3}$. Pairs of lenses were incubated aerobically in the presence and absence of glucose. At the end of the incubation period $\mathrm{NH}_{3}$ was measured in the medium (Kaplan, 1969).

\section{Results}

\section{Metabolism of ${ }^{14} \mathrm{C}$-labelled amino acids}

Alanine. The uptake of alanine by the lens in $22 \mathrm{~h}$ was over two-thirds of that originally in the medium (Table 1). A substantial part of this, $28.2 \%$, is lactate that was released into the medium. $\left[{ }^{14} \mathrm{C}\right]$ Lactate was the only metabolite of the amino acids studied that escaped into the medium. Only $1.8 \%$ of the alanine taken up was metabolized to $\mathrm{CO}_{2}$, and $4.2 \%$ was incorporated into protein. Analysis of the trichloroacetic acid-soluble material (Table 2) revealed that alanine was the major component, with small amounts of lactate, glutamate, glutathione and aspartate present as metabolites. Glutathione was always found on the two-dimensional chromatography papers as both GSH and GSSG; the values in Tables 2 and 4 are the sum of the two forms. Traces of radioactivity were also found in the lipid material.

Aspartate. Tables 1 and 2 show the results obtained

Table 1. Uptake and distribution of radioactivity as ${ }^{14} \mathrm{CO}_{2}$, protein and trichloroacetic acid-soluble material of lenses incubated with $\left[{ }^{14} \mathrm{C}\right]$ alanine, $\left[{ }^{14} \mathrm{C}\right]$ aspartate or $\left[{ }^{14} \mathrm{C}\right]$ glutamate

The results are adjusted to a value for the initial radioactivity in the medium of 9000 c.p.s. $/ 15 \mathrm{ml}$, and are the means \pm S.D. for six lenses.

${ }^{14} \mathrm{CO}_{2}$ (c.p.s./g of lens)

Trichloroacetic acid-soluble material (c.p.s./g of lens)

Lactate in medium (c.p.s./g of lens)

Protein (c.p.s./g of lens)

Total radioactivity taken up (c.p.s./g of lens)

$\%$ uptake by the whole lens of that originally in the medium

$\%$ of uptake as ${ }^{14} \mathrm{CO}_{2}$

$\%$ of uptake as trichloroacetic acid soluble

$\%$ of uptake as lactate in medium

$\%$ of uptake as protein

$\begin{array}{ccc}\text { Alanine } & \text { Aspartate } & \text { Glutamate } \\ 63 \pm 9 & 126 \pm 11 & 132 \pm 56 \\ 2262 \pm 160 & 94 \pm 11 & 250 \pm 128 \\ 965 \pm 125 & 0 & 0 \\ 145 \pm 15 & 21 \pm 5 & 27 \pm 11 \\ 3435 \pm 116 & 241 \pm 19 & 408 \pm 138 \\ 71.1 \pm 2.3 & 5.3 \pm 0.7 & 10.3 \pm 2.8 \\ 1.8 \pm 0.3 & 52 \pm 3 & 33 \\ 65.9 \pm 1.0 & 39 \pm 4 & 61 \\ 28.2 \pm 1.0 & 0 & 0 \\ 4.2 \pm 0.3 & 8.7 \pm 1.5 & 6\end{array}$

Vol. 136 
Table 2. Radioactivity in each compound detected in the trichloroacetic acid-soluble material from lenses incubated with $\left[{ }^{14} \mathrm{C}\right]$ alanine, $\left[{ }^{14} \mathrm{C}\right]$ aspartate or $\left[{ }^{14} \mathrm{C}\right]$ glutamate

The results are expressed as the amount of radioactivity in each compound as a percentage of the total in the fraction. For alanine the results are expressed as the mean \pm S.D. for five lenses; for aspartate as the mean \pm S.D. for three lenses, and for glutamate as the mean of two lenses.

$\begin{array}{lccc} & \text { Alanine } & \text { Aspartate } & \text { Glutamate } \\ \text { Alanine } & 92.7 \pm 2.0 & 15 \pm 1 & - \\ \text { Aspartate } & 1.5 \pm 0.6 & 14 \pm 2 & - \\ \text { Glutamate } & 1.2 \pm 0.4 & 43 \pm 6 & 75 \\ \text { Glutathione } & 0.4 \pm 0.2 & 21 \pm 3 & 8 \\ \text { Glutamine } & - & \text { Trace } & 13 \\ \text { Lactate* } & 4.2 \pm 1.4 & 7 \pm 7 & - \\ \text { Proline } & - & \text { Trace } & 3 \\ \text { Ophthalmic acid } & - & - & \text { Trace } \\ \text { Radioactivity in the fraction } & 2262 \pm 110 & 94 \pm 11 & 250 \pm 128\end{array}$

* Much lactate escaped into the medium (see Table 1).

with aspartate. Very little appears to have been taken up; about one-half of the uptake was found as ${ }^{14} \mathrm{CO}_{2}$ with less than $10 \%$ in the protein. The major compound in the acid-soluble fraction was glutamate, which accounted for $43 \%$ of the radioactivity. Glutathione contained a further $21 \%$. Only $14 \%$ was as aspartate. Small amounts of alanine and lactate were present as well as traces of glutamine and proline.

Glutamate. The results obtained with glutamate were more variable than with any of the other amino acids studied. A similar variability was found on incubating calf lenses with $\left[{ }^{14} \mathrm{C}\right]$ glutamate (P. Trayhurn, unpublished work). The lenses took up an average of $10.3 \%$ of the amino acid (Table 1). Onethird of this was metabolized to $\mathrm{CO}_{2}$, and $6 \%$ was incorporated into protein.

The radioactive compounds in the acid-soluble fraction are given in Table 2. Three-quarters of the radioactivity was present in glutamate, with glutamine as the major metabolite. There were small amounts of glutathione and proline, and traces of what was probably ophthalmic acid. The incorporation of glutamate into both glutathione and ophthalmic acid has been observed in the rabbit lens (Reddy et al., 1966). No radioactivity was detected in aspartate, alanine or lactate (Table 2).

Leucine. Just over one-half of the leucine was taken up in $22 \mathrm{~h}$, and nearly half of this was incorporated into protein (Table 3). ${ }^{14} \mathrm{CO}_{2}$ accounted for a further $5.1 \%$ of the radioactivity. Some was also incorporated into lipids. The specific radioactivity and the total radioactivity in lipids are given in Table 5. Separation of the lipids by t.l.c. revealed that all the main groups contained radioactivity.

The major component of the acid-soluble fraction was leucine (Table 4); glutamate accounted for $10.4 \%$ of the radioactivity. The other compounds present, namely glutathione, proline and glutamine, were all metabolites of glutamate.

Lysine. About one-quarter of the lysine in the medium was taken up by the whole lens, of which nearly one half was incorporated into protein (Table $3)$. Of the uptake, $1.3 \%$ was metabolized to $\mathrm{CO}_{2}$. Table 4 shows that of the remaining radioactivity, $94.4 \%$ was unchanged lysine. Small amounts of glutamate, glutathione, proline and glutamine were detected, along with two unidentified compounds. As with leucine, the catabolism of lysine in mammalian tissues results in the formation of acetyl-CoA (see Rodwell, 1969). Although the acetyl-CoA entered the tricarboxylic acid cycle and was incorporated into glutamate, none was detected in the lipids (Table 5).

Proline. In other tissues proline is synthesized from, and broken down to, glutamate (see Rodwell, 1969). Because we found that proline was synthesized from glutamate (Table 2), we decided to see whether the lens could also degrade it.

Table 3 shows that less than a quarter of the proline was taken up. ${ }^{14} \mathrm{CO}_{2}$ accounted for $3.4 \%$ of the uptake, and protein for $23.6 \%$. The acid-soluble fraction contained glutamate, from which the ${ }^{14} \mathrm{CO}_{2}$ was presumably derived. In addition to glutamate, glutathione, alanine and an unidentified compound were found as metabolites in the acid-soluble fraction (Table 6), but the major component was unchanged proline. The presence of alanine was surprising, since it was not formed from glutamate (Table 2).

The capsule of the lens contains a collagen-like protein (Pirie, 1951). Therefore we examined the capsular protein for radioactive hydroxyproline. After incubation of the lens in $\left[{ }^{14} \mathrm{C}\right]$ proline the capsule was stripped off and scraped free from con- 


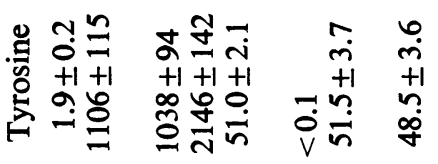

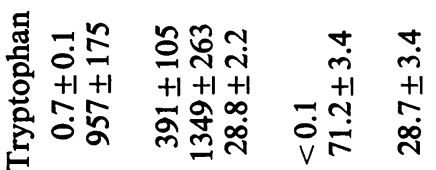

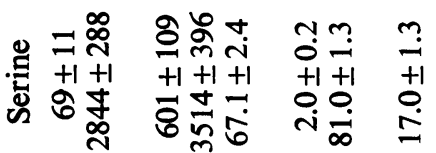

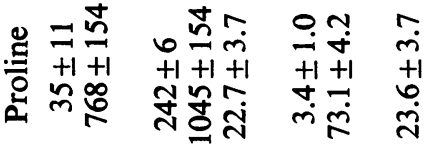

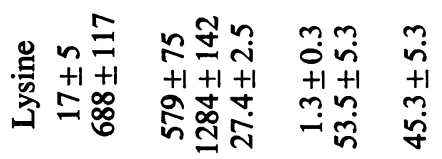
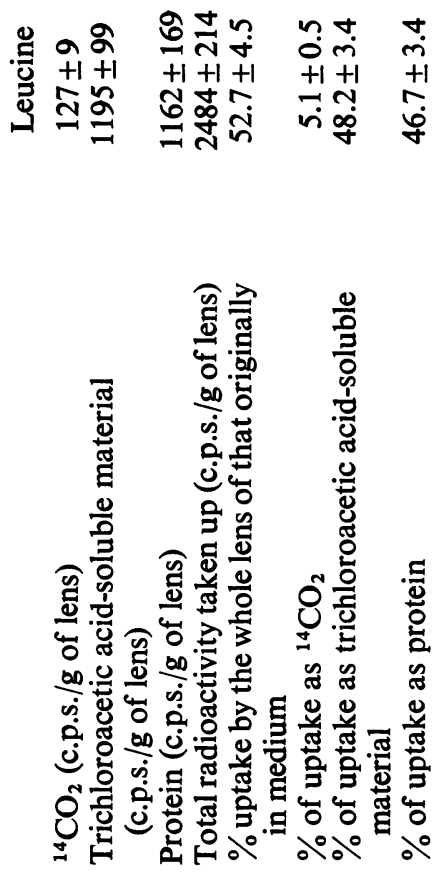

taminating tissue. It was washed well with water, a sample was hydrolysed in acid and the hydrolysate was separated on paper by the two-dimensional system as employed for acid-soluble lens extracts. After radioautography the radioactive spots were identified by reference to markers and by the use of the ninhydrin and isatin stains. Proline, hydroxyproline and glutamate were radioactively labelled.

Serine. About two-thirds of this amino acid was taken up in $22 \mathrm{~h}$, of which $2.0 \%$ was metabolized to ${ }^{14} \mathrm{CO}_{2} ; 17.0 \%$ was incorporated into protein (Table $3)$. Serine accounted for half of the radioactivity in the acid-soluble fraction (Table 4) and both glycine and cyst(e)ine became radioactive. Glutathione was the most labelled metabolite, the label presumably being in both the glycine and the cysteine of the tripeptide. Cysteine was oxidized to cystine in the isolation procedure. ATP and three unidentified compounds (D, E and F) were also present. Compound $\mathrm{D}$ had properties consistent with those of taurine but its identity was not confirmed. Taurine is a likely metabolite since it is formed in some tissues from cysteine. Dardenne \& Kirsten (1962) showed that the rabbit lens metabolizes methionine to taurine. The other two unidentified compounds ( $E$ and $F$ ) were both degraded by acid hydrolysis and by performic acid oxidation, suggesting that they are sulphur-containing peptides. No lactate was found in the acid-soluble extracts but traces were present in the medium.

The lipids were examined to see whether they had incorporated radioactivity from serine. The bovine lens contains phosphatidylserine, phosphatidylethanolamine and phosphatidylcholine (Broekhuyse, 1968). Ethanolamine and choline phosphatides may be formed from serine phosphatide (see Greenberg, 1969). Radioactivity was indeed found in the lipid extract (Table 5), the specific radioactivity being similar to that found with leucine. Although a definite identification was not made, t.l.c. of the extract revealed radioactivity in the position of phosphatidylserine, phosphatidylethanolamine and some other polar lipids situated near the origin.

Tryptophan. The uptake of tryptophan $(28.8 \%)$ may be affected by the use of a DL isomeric mixture (Table 3). Over one-quarter of the uptake was incorporated into protein. It appears that the bovine lens is unable to metabolize tryptophan, other than by incorporating it into protein, for negligible ${ }^{14} \mathrm{CO}_{2}$ was produced and no metabolites were present in the acidsoluble fraction.

Tyrosine. The bovine lens is also unable to metabolize tyrosine since there was no significant ${ }^{14} \mathrm{CO}_{2}$ formation (Table 3) and no compounds other than tyrosine in the acid-soluble fraction. About one-half of the tyrosine in the medium was taken up in $22 \mathrm{~h}$ and of this one-half was incorporated into protein (Table 3). 
Table 4. Radioactivity in each compound detected in the trichloroacetic acid-soluble material from lenses incubated with $\left[{ }^{14} \mathrm{C}\right]$ leucine, $\left[{ }^{14} \mathrm{C}\right]$ lysine, $\left[{ }^{14} \mathrm{C}\right]$ proline or $\left[{ }^{14} \mathrm{C}\right]$ serine

The results are expressed as the amount of radioactivity in each compound as a percentage of the total in the fraction. Each value is the mean \pm S.D. for six lenses.

\begin{tabular}{|c|c|c|c|c|}
\hline & Leucine & Lysine & Proline & Serine \\
\hline Leucine & $87.0 \pm 2.2$ & - & - & - \\
\hline Lysine & - & $94.4 \pm 2.2$ & - & - \\
\hline Proline & $0.5 \pm 0.1$ & $0.8 \pm 0.7$ & $90.7 \pm 1.0$ & - \\
\hline Serine & - & - & - & $51.7 \pm 3.2$ \\
\hline Glutamate & $10.4 \pm 2.1$ & $1.9 \pm 1.0$ & $3.0 \pm 0.4$ & - \\
\hline Glutathione & $2.1 \pm 1.8$ & $0.7 \pm 0.1$ & $1.8 \pm 0.8$ & $32.3 \pm 4.9$ \\
\hline Glutamine & Traces & & & - \\
\hline Alanine & - & - & $3.8 \pm 0.7$ & - \\
\hline Glycine & - & - & - & $10.9 \pm 1.6$ \\
\hline Cystine & - & 一 & - & $0.4 \pm 0.1$ \\
\hline ATP & - & - & - & $0.4 \pm 0.2$ \\
\hline Unknown compounds & & & & \\
\hline (A) & - & $1.5 \pm 0.5$ & - & - \\
\hline (B) & - & $0.9 \pm 0.7$ & - & - \\
\hline (C) & - & - & $0.7 \pm 0.5$ & - \\
\hline (D) & - & - & - & $1.1 \pm 0.2$ \\
\hline (E) & - & - & - & $1.9 \pm 0.5$ \\
\hline (F) & - & - & - & $1.3 \pm 0.7$ \\
\hline Lactate in the medium & - & - & - & Traces \\
\hline $\begin{array}{l}\text { Radioactivity in the fraction } \\
\text { (c.p.s./g of lens) }\end{array}$ & $2484 \pm 214$ & $688 \pm 117$ & $768 \pm 154$ & $2844 \pm 288$ \\
\hline
\end{tabular}

Table 5. Radioactivity incorporated into lipids of a lens incubated with $\left[{ }^{14} \mathrm{C}\right]$ alanine, $\left[{ }^{14} \mathrm{C}\right]$ leucine, $\left[{ }^{14} \mathrm{C}\right]$ lysine or $\left[{ }^{14} \mathrm{C}\right]$ serine

The results are each obtained from one lens. The total radioactivity is calculated from the specific radioactivity and by taking the lipid content of the adult bovine lens to be $0.25 \%$ of the wet weight, from the results of Anderson et al. (1969).

$$
\begin{array}{cc}
\begin{array}{c}
\text { Specific } \\
\text { radioactivity }
\end{array} & \begin{array}{c}
\text { Total radioactivity } \\
\text { in the lipid }
\end{array} \\
\text { (c.p.s./mg of lipid) } & \text { (c.p.s./g of lens) }
\end{array}
$$$$
\begin{array}{lcc}
\text { Alanine } & \text { Traces } & - \\
\text { Leucine } & 4.0 & 10 \\
\text { Lysine } & 0 & 0 \\
\text { Serine } & 3.6 & 9
\end{array}
$$

\section{Production of $\mathrm{NH}_{3}$ in the absence of added amino acids}

The production of $\mathrm{NH}_{3}$ by the lens was measured to see whether any significant breakdown of endogenous amino acids occurs. Pairs of lenses were incubated with and without added glucose. In the presence of glucose $0.91 \mu \mathrm{mol}$ of $\mathrm{NH}_{3} / \mathrm{g}$ of lens was produced in $22 \mathrm{~h}$ (Table 6). When glucose was absent this value was increased to $1.33 \mu \mathrm{mol} / \mathrm{g}$ of lens in $22 \mathrm{~h}$.
Table 6. Production of $\mathrm{NH}_{3}$ by lenses incubated in the presence or absence of glucose

The results are expressed as means \pm S.D. for six pairs of lenses. The difference between the two groups is statistically significant $(P<0.001)$ on the basis of a paired Student's $t$ test.

$\mathrm{NH}_{3}$ produced

( $\mu \mathrm{mol} / \mathrm{g}$ of lens in $22 \mathrm{~h}$ )

$\overbrace{\begin{array}{c}\text { +Glucose } \\ 0.91 \pm 0.10\end{array}}^{- \text {Glucose }} \quad \begin{array}{cc}\text { 1.33 } \pm 0.12 & \frac{- \text { Glucose }}{\text { +Glucose }} \times 100 \\ 146\end{array}$

Thus when the excised lens is solely dependent upon endogenous material for energy, more $\mathrm{NH}_{3}$ is produced, indicating greater amino acid breakdown.

\section{Discussion}

All nine of the amino acids studied here were taken up by the lens and incorporated into protein and this appears to be the sole way in which the bovine lens can metabolize the two aromatic amino acids, tryptophan and tyrosine. These compounds are therefore 
useful for studies on the active transport of amino acids into the lens and on protein synthesis when interference would be caused by their metabolism to other substances. Tyrosine has been used by us for this purpose (Trayhurn \& van Heyningen, 1972).

\section{Metabolism of amino acids}

Tyrosine. Dopa-quinone (the quinone derived from 3,4-dihydroxyphenylalanine), a metabolite of tyrosine, has been suggested as a possible cause of the 'browning' of the human lens in cataract (Srivastava $\&$ Beutler, 1969). The finding that the bovine lens and also the human lens (R. van Heyningen, unpublished work) do not metabolize tyrosine is evidence against this theory.

Tryptophan. The results obtained on the metabolism of tryptophan do not agree with those of Ciusa et al. (1964), who claimed that both the human and bovine lens formed derivatives of nicotinic acid from tryptophan. However, they did not use radioactively labelled tryptophan. Unlike the bovine lens, the human lens metabolizes tryptophan, with the formation of derivatives of kynurenine that are responsible for its non-protein fluorescence (van Heyningen, 1971, 1973). The colourless bovine lens does not contain these compounds. The other amino acids studied here were all metabolized by the bovine lens to give the end products expected from what is known about their metabolism in other mammalian tissues. This is strong evidence that the lens metabolizes them by the same pathways as in other tissues.

Lysine. Breakdown of lysine results in the formation of acetyl-CoA (see Rodwell, 1969). The presence of glutamate, glutathione and proline in the acidsoluble fraction indicates that acetyl-CoA was formed in the bovine lens and entered the tricarboxylic acid cycle. The fact that no radioactivity was detected in the lipids may be due to lack of sensitivity of the method or because acetyl-CoA formed from lysine did not enter the pathway for the synthesis of fatty acids. The small amount of ${ }^{14} \mathrm{CO}_{2}$ and metabolites in the acid-soluble fraction indicate that the bovine lens has a low capacity to catabolize lysine. Cotlier (1971) reported that the rabbit lens is unable to degrade lysine.

Leucine. Acetyl-CoA formed by the metabolism of leucine entered the tricarboxylic acid cycle and was incorporated into fatty acids. Acetyl-CoA and acetoacetate are normally produced by the catabolism of leucine in mammalian tissues (see Rodwell, 1969). In extrahepatic tissues leucine can be further degraded to acetyl-CoA (Williamson et al., 1971). Our results differ from those reported by Delcour \& Papaconstantinou (1972), who found no metabolites in trichloroacetic acid-soluble extracts of the bovine lens after incubation with radioactively labelled leucine.
The explanation for this discrepancy may be their shorter incubation period $(8 \mathrm{~h})$.

Proline. The bovine lens appears to be able to degrade proline to glutamate (Table 4), as well as synthesizing it from the same compound (Table 2). The detection of radioactivity in hydroxyproline in the capsule indicates that the tissue is able to hydroxylate the proline in the protein to hydroxyproline. A similar result has been observed for the rat lens ( $R$. van Heyningen \& A. Pirie, unpublished work). The finding that radioactive alanine is formed (Table 4) although it is not a product of the metabolism of glutamate (Table 2) may be evidence for the turnover of capsule collagen, since alanine is a breakdown product of hydroxyproline in mammalian tissues (Wolf \& Berger, 1958).

Aspartate and glutamate. These two acidic amino acids (Table 1) were the least readily taken up. Animal tissues are generally impermeable to glutamate (Ussing, 1943; Schwerin et al., 1950; Hems et al., 1968). The aspartate and glutamate taken up were readily metabolized, the proportion of the uptake converted into $\mathrm{CO}_{2}$ being greater than for the other amino acids $(52 \%$ for aspartate and $33 \%$ for glutamate). This is a consequence of their close relationship with the tricarboxylic acid cycle; transamination of aspartate yields oxaloacetate, and oxidative deamination of glutamate yields $\alpha$-oxoglutarate. The enzymes required for these reactions, aspartate aminotransferase and glutamate dehydrogenase respectively, are present in the bovine lens (Dardenne $\&$ Kirsten, 1962). Although much aspartate was converted into glutamate, the reverse reaction was not detected (Table 2). Similarly, although the entry of alanine (Table 2), leucine and lysine into the tricarboxylic acid cycle resulted in the incorporation of radioactivity into glutamate, aspartate was not labelled. This may reflect the fact that the lens has a greater demand for glutamate than aspartate, particularly for the synthesis of glutathione. The concentration of glutathione in the lens is greater than that of other tissues (Waley, 1969). Radioactivity appeared in glutathione not only when glutamate was the direct precursor (Table 2), but also when the labelled amino acid was aspartate, alanine (Table 2), leucine, lysine, proline or serine (Table 4).

Alanine. The major route for the metabolism of alanine by the lens appeared to be by transamination to pyruvate, which was then reduced to lactate which diffused into the medium (Table 2).

Serine. There was a large conversion of serine into glycine if, as seems probable, most of the radioactivity found in glutathione when the lens was incubated in serine was due to the glycine moiety (Table 4). The cysteine moiety was probably also labelled but to a much smaller extent. In experiments on the metabolism of glycine in the calf lens, a large conversion of glycine into serine was observed (Waley, 1964). The 
incorporation of radioactivity from serine into ATP and lactate (Table 6) is also consistent with the findings of the experiments with glycine (Waley, 1964).

\section{Tricarboxylic acid cycle oxidation}

Oxidation of a labelled amino acid by way of the tricarboxylic acid cycle leads to the formation of ${ }^{14} \mathrm{CO}_{2}$ (Tables 1 and 3 ) and incorporation of the label into glutamate (and glutathione) and proline (Tables 2 and 4). Aspartate and glutamate are oxidized to a considerable extent and alanine, proline, leucine and lysine to lesser degrees (Tables 1, 2, 3 and 4). To confirm that molecular $\mathrm{O}_{2}$ participates in the production of ${ }^{14} \mathrm{CO}_{2}$, the metabolism of labelled glutamate, aspartate and alanine was examined under anaerobic conditions (Trayhurn, 1972). The production of ${ }^{14} \mathrm{CO}_{2}$ from glutamate and alanine was almost abolished. With aspartate as substrate it was decreased to about $50 \%$ of its aerobic value; this can be reasonably explained by the persistence of reactions in which oxaloacetate, produced from aspartate by deamination, is decarboxylated without the participation of molecular $\mathrm{O}_{2}$ (Krebs \& Lowenstein, 1960).

\section{Amino acids as a source of energy}

The aerobic utilization of endogenous material provides a considerable amount of energy for the lens when it is incubated in glucose-free medium (Kinoshita et al., 1961 ; Trayhurn \& van Heyningen, 1971a, 1972).

Amino acids are a likely endogenous substrate (Trayhurn \& van Heyningen, 1971b). The experiments with ${ }^{14} \mathrm{C}$-labelled amino acids showed that the lens metabolizes amino acids by energy-producing reactions. To obtain more evidence, the production of $\mathrm{NH}_{3}$ by the lens was measured in the presence and absence of glucose (Table 6). When glucose is present in the medium $0.91 \mu \mathrm{mol}$ of $\mathrm{NH}_{3} / \mathrm{g}$ of lens is formed in $22 \mathrm{~h}$; under these circumstances $12 \mu \mathrm{mol}$ of glucose $/ \mathrm{g}$ of lens is consumed and $20.2 \mu \mathrm{mol}$ of lactate $/ \mathrm{g}$ of lens is formed (Trayhurn \& van Heyningen, 1972). Since oxidation of amino acids by the tricarboxylic acid cycle yields far more energy per mol oxidized than that derived from glycolysis, this result indicates that oxidation of amino acids contributes appreciably to the energy production by the lens. This suggestion is strengthened by the finding that, in the absence of glucose, the production of $\mathrm{NH}_{3}$ is increased by $46 \%$ (Table 6 ).

The lens has a monolayer of epithelial cells at its anterior surface. These contain most of the mitochondria in the tissue and are adjacent to the source of $\mathrm{O}_{2}$, in solution in the aqueous humour. The aqueous humour is also the source of all other substrates. In the adult bovine lens the epithelial cells constitute a minute proportion, perhaps about $0.1 \%$, of the total lens volume, but are probably responsible for nearly all metabolism involving molecular $\mathrm{O}_{2}$, and may supply about one-third of the energy produced by the lens (Trayhurn \& van Heyningen, 1972).

The contribution of the tricarboxylic acid cycle to theeconomy of the lens has been underestimated in the past, partly because of the small amount of ${ }^{14} \mathrm{CO}_{2}$ which is formed by the metabolism of $\left[6-{ }^{14} \mathrm{C}\right]$ glucose. Little of the pyruvate formed in glycolysis in the lens fibres is available to the epithelial mitochondria and it is largely reduced to lactate, which is liberated into the medium. The same seems to apply to pyruvate formed by deamination of alanine. Of the $\left[{ }^{14} \mathrm{C}\right]-$ alanine taken up by the lens $28.2 \%$ was recovered as lactate in the medium, whereas only $1.8 \%$ appeared as $\mathrm{CO}_{2}$ (Table 1). Alanine aminotransferase has been shown to occur throughout the body of the lens (Dardenne \& Kirsten, 1962) though it is not known if there is also a mitochondrial form of the enzyme, such as is found in other tissues (Sallach \& Fahien, 1969). It seems that alanine is largely deaminated in the lens fibres and the pyruvate formed is reduced to lactate. Only a small proportion is oxidized to $\mathrm{CO}_{2}$ via acetylCoA and the tricarboxylic acid cycle.

In contrast, glutamate dehydrogenase is probably exclusively a mitochondrial enzyme in the lens as in other tissues (Sallach \& Fahien, 1969). Glutamate obtained from the aqueous humour or that formed from glutamine (Trayhurn \& van Heyningen, 1973), or from aspartate by transamination, is metabolized in the epithelial cells entering the tricarboxylic acid cycle as $\alpha$-oxoglutarate.

\section{Comparison of the lens with other tissues}

In the lens glycolysis is the major source of energy, but from the experiments in the present paper it appears that oxidation of amino acids is also important. It is difficult to compare the quantitative importance of the metabolism of amino acids in the lens with that in other tissues.

Krebs (1972) has discussed the question 'What are the fuels of respiration of major organs and tissues?' On the subject of amino acids he says that 'the majority can be degraded in the liver and the kidney but information on the extent to which other organs are sites of amino acid degradation is very limited'. He suggests that a major rate-limiting factor in the degradation of external amino acids is the rate of penetration of the amino acid into the cell.

We thank Dr. H. G. Epstein and Mr. C. Hahn of the Nuffield Department of Anaesthetics, Radcliffe Infirmary, Oxford, for the use of their computer.

\section{References}

Amoore, J. E., Bartley, W. \& van Heyningen, R. (1959) Biochem. J. 72, 126-136

Anderson, R. E., Maude, M. B. \& Feldman, G. L. (1969) Biochim. Biophys. Acta 187, 345-353 
Atfield, G. N. \& Morris, C. J. O. R. (1961) Biochem. J. 81, 606-614

Beloff-Chain, A., Cantanzaro, R., Chain, E. B., Masi, I., Pocchiari, F. \& Rossi, C. (1955) Proc. Roy. Soc. Ser. B 143, 481-503

Bradford, H. F., Chain, E. B., Cory, H. T. \& Rose, S. P. R. (1969) J. Neurochem. 16, 969-978

Broekhuyse, R. M. (1968) Biochim. Biophys. Acta 152, 307-315

Calam, D. H. (1962) Exp. Eye Res. 1, 436-442

Calam, D. H. \& Waley, S. G. (1964) Biochem. J. 93, 526532

Ciusa, W., Cristini, G. \& Barbiroli, G. (1964) Exp. Eye Res. 3, 169-178

Cohen, P. P. (1949) in Manometric Techniques and Tissue Metabolism (Umbreit, W. W., Burris, R. H. \& Stauffer, J. F., eds.), p. 119, Burgess Publishing Co., Minneapolis

Cotlier, E. (1971) Biochim. Biophys. Acta 241, 798-806

Dardenne, U. \& Kirsten, G. (1962) Exp. Eye Res. 1, 415421

Delcour, J. \& Papaconstantinou, J. (1972) J. Biol. Chem. 247, 3289-3295

Gray, D. O. \& Weitzman, P. D. J. (1969) in Data for Biochemical Research, 2nd edn. (Dawson, R. M. C., Elliott, D. C., Elliot, W. H. \& Jones, K. M., eds.). pp. 52-53, Oxford University Press, Oxford.

Greenberg, D. M. (1969) Metab. Pathways 3rd edn., 3, 237-315

Griffiths, M. H. (1966) Biochem. J. 99, 12-21

Hems, R., Stubbs, M. \& Krebs, H. A. (1968) Biochem. J. 107, 807-815

Hirs, C. H. W. (1967) Methods Enzymol. 11, 59-62

Hughes, D. E. \& Williamson, D. H. (1951) Biochem. J. 48, 487-490

Kaplan, A. (1969) Methods Biochem. Anal. 17, 311319

Kern, H. L. (1962) Invest. Ophthalmol. 1, 368-376

Kinoshita, J. H., Kern, H. L. \& Merola, L. O. (1961) Biochim. Biophys. Acta 47, 458-466

Kinsey, V. E. \& Reddy, D. V. N.(1963) Invest. Ophthalmol. 2, 229-236

Krebs, H. A. (1972) Advan. Enzyme Regul., 2, 397-420

Krebs, H. A. \& Lowenstein, J. M. (1960) Metab. Pathways, 2nd edn., 1, 171

Merriam, F. C. \& Kinsey, V. E. (1950a) AMA Arch. Ophthalmol. 43, 979-988
Merriam, F. C. \& Kinsey, V. E. (1950b) AMA Arch Ophthalmol. 44, 651-658

Muldner, H. G., Wherrett, J. R. \& Cumings, J. N. (1962) J. Neurochem. 9, 607-611

Pirie, A. (1951) Biochem. J. 48, 368-371

Reddy, D. V. N. (1967) Invest. Ophthalmol. 6, 478-483

Reddy, D. V. N. (1970) Invest. Ophthalmol. 9, 206-219

Reddy, D. V. N. (1971) Exp. Eye Res. 11, 310-328

Reddy, D. V. N. \& Kinsey, V.E. (1962) Invest. Ophthalmol. 1, 635-641

Reddy, D. V. N., Klethi, J. \& Kinsey, V. E. (1966) Invest. Ophthalmol. 5, 594-600

Rodwell, V. W. (1969) Metab. Pathways, 3rd edn., 3, 191-235

Sallach, H. J. \& Fahien, L. A. (1969) Metab. Pathways 3rd edn., 3, 1-94

Schwerin, P., Bessman, S. P. \& Waelsch, H. (1959) J. Biol. Chem. 184, 37-44

Smith, I. (1969) Chromatographic and Electrophoretic Techniques 3rd edn., vol. 1, p. 120, Heinemann, London

Srivastava, S. K. \& Beutler, E. (1969) Biochem. J. 112, 421-425

Trayhurn, P. (1972) D.Phil. Thesis, University of Oxford

Trayhurn, P. \& van Heyningen, R. (1971a) Exp. Eye Res. 12, 315-327

Trayhurn, P. \& van Heyningen, R. (1971b) Biochem. J. 124, 72P-73P

Trayhurn, P. \& van Heyningen, R. (1972) Biochem. J. 129, 507-509

Trayhurn, P. \& van Heyningen, R. (1973) Exp. Eye Res. 17 , in the press

Udenfriend, S. \& Cooper, J. R. (1952) J. Biol. Chem. 194, 503-511

Ussing, H. H. (1943) Acta Physiol. Scand. 5, 335-351

van Heyningen, R. (1965) Biochem. J. 96, 419-431

van Heyningen, R. (1971) Nature (London) 230, 393-394

van Heyningen, R. (1973) Exp. Eye Res. 15, 121-126

Waley, S. G. (1964) Biochem. J. 91, 576-583

Waley, S. G. (1969) in The Eye 2nd edn. (Davson, H., ed.), vol. 1, p. 352, Academic Press, New York and London

Williamson, D. H., Bates, M. W., Page, M. A. \& Krebs, H. A. (1971) Biochem. J. 121, 41-47

Wolf, G. \& Berger, C. R. A. (1958) J. Biol. Chem. 230, 231-240 